\title{
Implementation of E-Learning for ESP in Tourism During the Covid-19 Pandemic
}

\author{
Gede Ginaya \\ Department of Tourism, Bali State Polytechnic, Jl. Bukit Jimbaran, South Kuta, Badung, Bali, Indonesia \\ Ni Putu Somawati \\ Department of Tourism, Bali State Polytechnic, Jl. Bukit Jimbaran, South Kuta, Badung, Bali, Indonesia \\ I Gusti Agung Bagus Mataram \\ Department of Tourism, Bali State Polytechnic, Jl. Bukit Jimbaran, South Kuta, Badung, Bali, Indonesia
}

\begin{abstract}
Covid-19 has been declared a global pandemic by WHO. This affects all aspects of human life, including education. The entire teaching and learning process during the Covid-19 pandemic was carried out online or by implementing e-learning. The online system of study intends to avoid human contact. This study aims to look at the media used to implement e-learning, considerations in choosing e-learning media, as well as the advantages and disadvantages found in implementing e-learning. There are six English lecturers who teach Tourism English at Tourism Department of Bali State Polytechnic. The data used in this study were obtained from questionnaires distributed online. The data is then analyzed by looking for a percentage and describing it.
\end{abstract}

Index Terms —Covid-19 pandemic, E-learning, tourism English learning

\section{INTRODUCTION}

The world was shocked by the outbreak of the corona virus in early 2020. The virus, which is said to have originated in Wuhan, China in December 2019, has infected almost all countries in the world (Huang, et al, 2020). This has resulted in a global crisis where the most obvious impact is on the tourism sector. The existence of an international travel ban has affected more than $90 \%$ of the global population accompanied by the imposition of social distancing has made the tourism industry practically suspended in March 2020 (Grech, et al, 2020).The first case of the Corona virus in Indonesia occurred in Depok, West Java, to be precise on March 2, 2020 (Nuraini, 2020). This case of transmission of the virus began when a Japanese citizen met an Indonesian citizen, a 31-year-old woman, at a dance club on February 14, 2020.Then the corona virus spread to various regions in Indonesia with the capital city of Jakarta as the epicenter. As of May 13, 2020, there were 15,438 positive cases in Indonesia with details of 3,287 patients having been declared cured, 1,028 patients declared dead, and the rest are still undergoing treatment (Task Force for the Acceleration of Handling Covid-19, 2020). These cases are spread across 34 provinces in Indonesia.

Seeing the rapid development and transmission of the Coronavirus, the Indonesian Government is taking various ways to deal with it. One of them is the policy of studying from home. The Minister of Education and Culture of the Republic of Indonesia through a notification letter number 36962 / MPK.A / HK / 2020 appealed to all university leaders, heads of higher service institutions, heads of provincial education offices, heads of district / city education offices, and heads of technical implementation units of the Ministry of Education and Culture of the Republic of Indonesia to postpone activities that invite and gather mass and replace them with teleconferences or other online activities. In response to this, The Governor of Bali Province also issued a notification letter number 60 / Task Force Covid-19 / III / 2020 which appealed to the Head of the Education Unit in Bali to organize learning online up to a deadline that is not determined.

Based on this fact, education units, from the lowest to higher education, organize online education by utilizing the existing technology. This phenomenon becomes the background of this research. There are three main focuses examined in this research, namely (1) media and categories of implementation of e-learning or online learning, (2) determining factors or considerations in choosing e-learning media, and (3) advantages and disadvantages found in implementation of e-learning.

\section{CONCEPTS AND THEORY}

Concepts and theories discuss the theories that are the basis for conducting this research, including the notion of elearning, characteristics and components of e-learning, categories of e-learning, advantages and disadvantages of elearning, and choosing e-learning media.

A. Definition of E-learning 
E-learning or what is also often referred to as online learning has a broad and different definition. But broadly speaking, these definitions have one thing in common, namely the existence of learning and the involvement of technology. Several experts in the field of e-learning or online learning expressed their opinion about the definition of elearning. The definition created by this expert sees e-learning from various points of view so as to produce different meanings or definitions.

The term e-learning actually comes from 2 words in English, namely electronic and learning (Mutia \& Leonard, 2013). Then, literally, e-learning can be interpreted as learning that is carried out using electronic media. Specifically, elearning refers to the use of the internet and technology to provide various solutions to increase knowledge and skills (Jethro et al, 2012). This understanding shows that the purpose of using e-learning is to increase one's knowledge and skills by utilizing technology and the internet. The solutions and materials used to improve these abilities and skills are provided and delivered using technology and the internet, such as the use of video, website and audio. Horton (2011) in Kattoua et al (2016) also has the same idea that e-learning is a set of learning delivered through electronic media, such as the internet, intranet, and extranet. The two definitions indicate the important role of technology in the learning process. Learning can be said to implement elearning if there is technology in it.

Furthermore, Paulsen (2003) states that e-learning is an interactive learning where students will get input from their learning activities automatically and the availability of online learning resources and materials (Bezhovski \& Poorani, 2016). It is also said that e-learning is learning that uses telecommunications to convey information and learning materials so that this type of learning does not use learning materials in the form of printed books (Goyal, 2012). This definition states the same thing, namely in the process of implementing e-learning the interaction between educators and students occurs online. Not only interaction, learning materials are also presented online so that text books or other printed materials are no longer used.

As technology develops, the use of e-learning is also increasingly prevalent. Alshehri et al (2019) said that e-learning is the latest form of learning that attracts the attention and interest of teachers in the world. Much of the learning has been done online. This can be seen from the number of online classes that can be accessed by anyone, anytime and anywhere. Looking back, e-learning is nothing new. E-learning has been around for a long time. Howe \& Knutzen (2012) quoted from Belaya (2018) stated that the concept of e-learning has existed since the 1990s. Eickhoff (2008) in Belaya (2018) believes that e-learning is not a new knowledge transfer method, but a way of presenting and delivering material using new media. Based on this opinion, e-learning tends to lead to the use of new media to convey and transfer information and knowledge to students. When e-learning was not yet developed, learning materials were presented in written and printed form, such as textbooks and other analog materials. However, with e-learning, the printed material is no longer used and has switched to digital forms, such as e-books.

\section{B. Characteristics and Components of E-learning}

The implementation of e-learning can be easily marked and recognized by the use of technology and electronic media in the learning process. However, in essence e-learning is still a learning process that involves educators, students, and all supporting materials. Bernard Luskin, one of the pioneers of e-learning, even interpreted the letter "e" in the term elearning as enthusiastic, emotional, extended, excellent, and educational (Obuekwe \& Eze, 2017). In addition, the letter "e" in the term e-learning can also be interpreted as exploration, experience, engagement, ease to use, and empowerment (Mutia \& Leonard, 2013).

E-learning is expected to be able to provide opportunities for students to explore learning topics through learning resources available on the internet. So that e-learning allows students to gain experience learning according to their interests, talents, and abilities. The use of technology in e-learning is also expected to be able to attract students' interest and engagement in learning so that they can foster creativity and critical thinking skills. In addition, e-learning should also be easy to access and can empower students in learning.

Apart from having characteristics, e-learning also has components that ensure that e-learning runs well and smoothly so that learning objectives can be achieved (Ginaya, et al, 2020). Gottschalk (1995) mentions 5 important components in the implementation of e-learning (Mutia \& Leonard, 2013).

a. Students are the main component in e-learning. If students are not there, e-learning cannot take place. Elearning is said to be effective if it is able to facilitate the needs of students.

b. Instructor as another major component. The instructor in the teaching and learning process has a very important role. An instructor must know the needs and characteristics of his students so that he/she can design effective elearning. In addition, instructors also act as helpers who are always ready to help students when they need help in learning.

c. Facilitator in e-learning as a supporting component. The facilitator acts as an extension of the instructor's hand. The facilitator is in charge of preparing equipment, supervising exams, and submitting assignments.

d. Support staff. The support staff has almost the same duties as the facilitator who is responsible for arranging the scheduling, duplication and distribution of materials, and value processing.

e. Administrators. Administrators in this case lead to managerial functions that are tasked with making decisions, making agreements, and conducting evaluations and ensuring that the academic focus remains in accordance with the vision and mission. 


\section{E-learning Category}

As with the definition of e-learning, the category of e-learning also varies depending on the point of view used to classify it. The German Federal Academy of Public Administration divides e-learning into four forms, namely individual learning, tutorially supported learning, collaborative learning, and blended learning (Belaya, 2018).

a. Individual learning is a type of e-learning that provides freedom for students to regulate their learning methods. In this form, only learning materials and resources available in the media are used online and there is no monitoring process from educators.

b. Tutorially supported learning is a different type of individual learning. In individual learning, students do not get supervision from educators, while tutorially supported learning provides supervision for students.

c. Collaborative learning is a learning process that occurs and involves virtual communities, such as classes.

d. Blended learning is a combination of several types of learning. Blended learning combines individual learning, face-to-face learning and group work.

In addition to the four types of e-learning above, Horton divides e-learning into five major classifications, namely learner-led e-learning, instructor-led e-learning, facilitated e-learning, embedded e-learning, telementoring and ecoaching (Mutia \& Leonard, 2013).

a. Learner-led E-learning has in common with individual learning where students can learn independently. All learning materials and resources are posted online.

b. Instructor-led E-learning is a type of e-learning in which educators present online learning material. This is like a face-to-face meeting, but done online.

c. Facilitated E-learning is a combination of learner-led e-learning and instructor-led e-learning.

d. Embedded E-learning is a just in time training where educators can provide assistance immediately when students need it.

e. Telementory and e-coaching are distance learning and training guidance and are carried out like teleconferencing.

\section{Pros and Cons of E-learning}

E-learning has a variety of advantages that can be obtained by both students and educators themselves.

Some of the advantages of using e-learning (Mutia \& Leonard, 2013) are as follows.

a. The implementation of e-learning can reduce costs incurred for the learning process, such as the absence of costs for purchasing textbooks and printing tests and study materials.

b. The implementation of e-learning allows educators and students to have the flexibility of time, place, speed of learning.

c. E-learning has the same standards and effectiveness of learning. Whenever students access teaching resources and materials, the quality and standards of the sources and teaching materials remain the same.

In addition, other advantages will also be obtained from the implementation of e-learning, namely increasing interaction between students and educators and enabling students to learn according to their learning abilities and speed (Arkkorful \& Abaidoo, 2015).

The implementation of e-learning allows for an increase in the quality of relationships and communication that occur between students and educators. Online education eliminates the existing boundaries between educators and students so there is no awkwardness for students to communicate and express their opinions. In addition, e-learning provides opportunities for students to learn according to their own abilities.

However, e-learning also has shortcomings that can be taken into consideration for educators in deciding the use of elearning (Mutia \& Leonard, 2013).

a. Students and educators must have good computers and internet access so that learning can run well.

b. Students will feel confused in learning considering the absence of class routines so that it will be a threat to students.

c. Students and educators will have long distances in the absence of face-to-face meetings.

\section{E. Choosing E-learning Media}

In selecting media for the implementation of e-learning, there are several factors that can be considered by educators (Clarity Innovations).

a. The selection of media for the implementation of e-learning should consider the learning objectives to be achieved at the end of the class.

b. The budget that is owned by educators is that some media require users to make payments to get additional features.

c. Learning activity plans can also be a consideration for having e-learning media, such as interactive communication support, videos, and other digital media.

d. The type of assessment provided by e-learning media is also a consideration in choosing e-learning media.

e. The type of communication supported by the media can also be taken into consideration for having e-learning media.

f. The media design used for e-learning is one of the considerations for choosing e-learning media.

g. Media accessibility can also determine whether a media can be used to carry out e-learning. 
h. The technical support provided is also an important factor in selecting media.

\section{RESEARCH METHODS}

This research was designed as a descriptive study. Descriptive research is research that aims to describe an event and its characteristics and leads to the "what" question (Nassaji, 2015). This study involved six English lecturers who teach at Tourism Department of Bali State Polytechnic. Data from six lecturers were obtained using online questionnaires. The data collected is then analyzed and interpreted so that conclusions can be drawn.

\section{RESULTS AND DISCUSSION}

This research focuses on the implementation of e-learning for the English course Tourism in Tourism Department of Bali State Polytechnic during the Covid-19 pandemic. The results of the analysis refer to three important things related to the implementation of e-learning, namely the media used to implement e-learning, considerations in choosing the media used, and the advantages and disadvantages of implementing e-learning that were found and felt during elearning during the Covid-19 pandemic. Apart from these three things, the study also found that 50\% of the respondents (three people) organized e-learning for the first time. Two out of six lecturers $(33.3 \%)$ said that they had implemented elearning before the Covid-19 pandemic.

\section{A. E-learning Media}

There are various learning management systems (LMS) or learning management systems available today. In fact, educators can take advantage of social media and instant message features to carry out e-learning. The data obtained from respondents in this study shows a tendency in the selection of media used to implement e-learning.

a. Google Classroom

All respondents (100\%) said that they used Google Classroom to organize e-learning for Tourism English courses. Google Classroom is the most popular medium for educators in implementing e-learning. This platform provides facilities for interactive communication in text form.

b. Zoom

There are 5 respondents $(83.3 \%)$ who also use the Zoom application to implement e-learning. This application allows educators and students to meet face to face online so that educators can provide instructions and explain teaching materials directly.

\section{c. Edmodo}

Only 1 respondent (16.7\%) used the Edmodo application to organize e-learning. Edmodo is an e-learning application that allows users to upload teaching materials and conduct discussions online.

d. WhatsApp

In addition to the three applications and platforms mentioned, some lecturers also take advantage of the WhatsApp instant message application by using the video call or video message feature.

e. YouTube

YouTube is also one of the media used by lecturers to organize e-learning. Students can access videos that are relevant to the learning topic being studied.

The media selection is based on several categories of e-learning conducted by the respondents. This is in accordance with the e-learning category put forward by Horton, quoted from Mutia \& Leonard (2013).

\section{a. Facilitated E-learning}

Five out of six respondents $(83.3 \%)$ said that the teaching material was sent online and then carried out interactive communication with students. The lecturer provided further explanation about the material and learning topics so that confusion and student problems during online learning could be answered and assisted by the lecturer concerned.

\section{b. Learner-led E-learning}

There were two lecturers out of six respondents who only uploaded materials and learning resources online and then provided opportunities for students to study independently according to their learning abilities.

c. Instructor-led E-learning

Similar to learner-led e-learning, there were two respondents who said that the respondents explained all learning materials and topics in an interactive and communicative manner without uploading learning materials online.

\section{d. Embedded E-learning}

There was only one respondent who did embedded e-learning, which was only giving directions to students if they needed help and guidance. Lecturers provided opportunities for students to find and find suitable learning materials and resources. If there was a problem, students could ask questions and ask for help from the lecturer.

From the results of the analysis of the media and the e-learning categories used by research respondents, it can be seen that the lecturers who are the respondents of this study tend to implement facilitated learning where the respondents will upload learning materials and resources online and then provide an explanation of the material and topics. Seeing the trends in the e-learning categories being used, Google Classroom provides features that can support these e-learning categories. 


\section{B. Factors to Consider the Selection of E-learning Media}

In choosing the e-learning media to be implemented, the respondents have several factors to consider. The results of the analysis show several factors that are thought by respondents in determining the e-learning media.

a. Accessibility

Media accessibility is an important factor that determines whether users will use a media or not. An e-learning media should have easy accessibility. The easier the accessibility, the more attractive it is to users. This factor was chosen by five out of six respondents $(83.3 \%)$.

b. Supported media devices

Teaching and learning activities involve a variety of media, such as audio, visual, and even audiovisual. Reflecting on this, it is important for educators to consider support for ease of uploading instructional media. E-learning platforms or LMS that are compatible with various types of learning media will be widely used. Some LMSs and e-learning platforms do not provide access to upload videos and some do not have the feature to upload images. As many as four out of six respondents (66.7\%) agreed that supporting media was important in choosing an LMS or e-learning platform.

c. Communication features provided

The results of the analysis of the applied e-learning category found that respondents tended to carry out facilitated elearning. This is what makes the communication features available in an LMS and e-learning platform one of the factors of consideration for educators in choosing e-learning media. The more communication features provided, the more users tend to choose it. It is also not surprising why there are various e-learning media used by respondents where the selection is based on the type of communication required. This was stated by four out of six respondents $(66.7 \%)$.

d. Assessment process and type

The types and assessment systems provided by e-learning media are important factors in choosing a medium for implementing e-learning. Assessment cannot be separated from the teaching and learning process. There are various types of assessment used in the learning process that are tailored to the things or learning improvements that want to be measured. Three out of six respondents (50\%) stated that it was important to consider the types of assessment available in an LMS or e-learning platform.

e. Design

Design is also a consideration for respondents to choose an e-learning media. Design will add to the aesthetic value of a lesson. There are three out of six respondents (50\%) who stated that design is a factor in choosing the media to implement e-learning.

f. Price

Some LMSs and e-learning platforms require their users to pay a certain price or subscribe to enjoy some of the additional features provided. Judging from the media used, respondents tend to choose e-learning media that is not paid, such as Google Classroom, Edmodo, Zoom, and WhatsApp and YouTube. Almost all respondents agree that price is a consideration in choosing media to implement e-learning. These considerations are in line with what is contained in the Learning Management System Toolkit written by Clarity Innovations, namely accessibility, supporting media, communication features, types of assessment supported, design, and price.

\section{The Advantages and Disadvantages of Implementing E-learning}

The final focus discussed in this study is the advantages and disadvantages of implementing e-learning that were encountered and felt by respondents in implementing e-learning during the Covid-19 pandemic. Based on the results of the analysis, the advantages of implementing e-learning can be explained as follows.

a. Provide opportunities for students to study according to their abilities

As many as $83.3 \%$ or five out of six respondents agreed that the implementation of e-learning provides opportunities for students to study according to their abilities. Students are not forced to study beyond their ability and speed so that students do not feel overwhelmed in the learning process. This is in accordance with Arkkorful \& Abaidoo (2015).

b. Provide opportunities for students and lecturers to be more innovative and creative

There are five out of six respondents who stated that the implementation of e-learning provided opportunities for students and lecturers to be more innovative and creative. With the use of technology, it always makes students and lecturers find new ways of learning. This is in line with what was stated by Jethro et al (2012).

c. Provides flexibility in study time

Mutia \& Leonard (2013) stated that the implementation of e-learning allows students and teachers to have flexible time. This is supported by the results of the analysis in this study where there were four out of six respondents who stated that they had flexible time in learning.

d. Provide easy access to learning resources

The use of technology and the internet in the implementation of e-learning makes it easy for students and lecturers to access learning resources. As many as $50 \%$ of respondents agreed to this advantage.

In addition to finding the advantages of implementing e-learning, respondents also encountered several shortcomings that were present in the implementation of online Tourism English learning. The results of the analysis of the shortcomings in the use of e-learning are described as follows.

a. Uneven internet access 
Uneven internet access is a fundamental issue encountered in the implementation of e-learning. As stated by Mutia \& Leonard (2013), to get an effective e-learning process, students and lecturers must have good internet access and equipment. A total of five people out of six respondents encountered this problem in implementing e-learning.

b. Limitations of the types of assessments available

This type of assessment is an important focus in the teaching and learning process. This was stated by four out of six respondents who were involved in this study.

c. The interaction between lecturers and students becomes more distant

Mutia \& Leonard (2013) said that the implementation of e-learning can result in the interaction between students and lecturers being not warm. This was also found by $50 \%$ of respondents who joined this study. The three respondents agreed that the absence of face to face results in the relationship and communication between students and lecturers becoming distant.

In its implementation, e-learning provides several benefits for both students and lecturers. But on the other hand, several obstacles were also found in its implementation.

\section{CONCLUSIONS AND SugGestions}

The implementation of e-learning in learning English in Tourism during the Covid-19 pandemic is nothing new for the lecturer who teaches the Tourism English course at the Bali State Polytechnic Tourism Department. They choose the media for implementing e-learning based on several factors of consideration, including accessibility, supporting media, and communication features. The implementation of e-learning in tourism English learning has various advantages or benefits but also has several obstacles that must be faced by students and lecturers. One of the obstacles that are a scourge especially for students is the internet quota they have to buy which can burden their parents in the midst of a pandemic where many of their parents are affected, such as being laid off and reducing their income.

The implementation of online learning in the Tourism Department of Bali State Polytechnic, which includes the English Tourism course in the three study programs, is getting used to teaching lecturers, especially after the IT lecturer team in the Department created an online course evidence management system (SIMBUKULON). The online lecture reporting system can be accessed by lecturers who teach courses in the Department by using the employee's registered number or NIP as a password, making it easier for them to upload proof of their online lectures after the learning-catchup process is complete. In addition, the online lecture proof files for each lecturer are stored neatly in SIMBUKULON. It can be suggested that lecturers who teach Tourism English courses should be even more creative in creating innovative Tourism English learning content by collaborating with IT lecturers and core subject lecturers to make learning more contextual and integrated between language and content.

\section{ACKNOWLEDGEMENTS}

The author expresses his gratitude to the parties who have contributed and encouraged the completion of this article as follows.

1. Kementerian Riset dan Technologi Pendidikan Tinggi or the Ministry of Technology and Research of Higher Education who funded the authors' research in the scheme of Penelitian Terapan Unggulan Perguruan Tinggi (PTUPT) or the Excellence of Higher College Applied-Research 2020.

2. Ni Made Ernawati and A.A.A. N. Harmini as Chair of the Department and Tourism Study Program, the Bali State Polytechnic who gives author permission to conduct research in the Tourism Business Study Program.

3. 3th Semester Student Tourism Business Travel Program Academic Year 2020/2021.

4. Prof. Dr. Ni Putu Kerti Nitiasih, MA who validates research instruments in the form of tests.

\section{REFERENCES}

[1] Alshehri, A., Rutter, M., \& Smith, S. (2019). Assessing the Relative Importance of an E-Learning System's Usability Design Characteristics Based on Students' Preferences. European Journal of Educational Research, 8(3), 839-855.

[2] Arkorful, V., \& Abaidoo, N. (2015). The Role of E-learning, Advantages and Disadvantages of Its Adoption in Higher Education. International Journal of Instructional Technology and Distance Learning, 12(1), 29-42.

[3] Belaya, V. (2018). The Use of E-Learning in Vocational Education and Training (VET): Systematization of Existing Theoretical Approaches. Journal of Education and Learning, 7(5), 92-101.

[4] Bezovski, Z., \& Poorani, S. (2016, March). The Evolution of E-learning and New Trends. In Information and Knowledge Management (Vol. 6, No. 3, pp. 50-57). IISTE.

[5] Clarity Innovations. (nd). Learning Management System Toolkit. Retrieved from K12 Blueprint: https://www.k12blueprint.com/ sites / default / files / Learning-Management-System-Guide.pdf. Retrieved April 03, 2021 from http://edure.org/EdureJournal.htm.

[6] Ginaya, G., Astuti, N. N. S., Mataram, I. G. A. B., \& Nadra, N. M. (2020, July). English Digital Material Development of Information Communication Technology ICT in Higher Vocational Education. In Journal of Physics: Conference Series (Vol. 1569, No. 2, p. 022009). IOP Publishing.

[7] Goyal, S. (2012). E-learning: Future of Education. Journal of Education and Learning, 239-242. Task Force for the Acceleration of Handling Covid-19. (2020, May 13). Infographic on COVID-19 (13 May 2020). Retrieved from the Task Force 
for the Acceleration of Handling Covid-19. Retrieved April 03, 2021 from https://covid19.go.id/p/berita/infogografi-covid1913-mei-2020.

[8] Grech, V., Grech, P., \& Fabri, S. (2020). A Risk Balancing Act-Tourism Competition Using Health Leverage in the COVID19 Era. International Journal of Risk \& Safety in Medicine, (Preprint), 1-5.

[9] Huang, C., Wang, Y., Li, X., Ren, L., Zhao, J., Hu, Y., \& Cao, B. (2020). Clinical Features of Patients Infected with 2019 Novel Coronavirus in Wuhan, China. The lancet, 395(10223), 497-506.

[10] Jethro, O. O., Grace, A. M., \& Thomas, A. K. (2012). E-learning and Its Effects on Teaching and Learning in a Global Age. International Journal of Academic Research in Business and Social Sciences, 2(1), 203-210.

[11] Kattoua, T., Al-Lozi, M., \& Alrowwad, A. (2016). A Review of Literature on E-learning System in Higher Education. International Journal of Business Management and Economic Research, 754-762.

[12] Kuimova, M., \& Kiyanitsyna, AT. (2015). E-learning as A Means to Improve the Quality of Higher Education. SHS Web of Conference, (pp. 1-5).

[13] Mutia, I., \& Leonard. (2013). Study of the application of e-learning in the learning process in higher education. The Exacta Factor, 6(4), 278-289.

[14] Nassaji, H. (2015). Qualitative and Descriptive Research: Data Type versus Data Analysis. Language Teaching Research, 1(1), 129-135.

[15] Nature, Sarah Oktaviani. (2020). The Journey of the Corona Outbreak in Indonesia Up to 100 Thousand Cases.https://health.detik.com/berita-detikhealth/d-5110667/ accessed December 3, 2020.

[16] Nuraini, R. (2020, March 2). The First Covid-19 Case, People Don't Panic. Retrieved from Indonesia.go.id. Retrieved April 03, 2021 from https://indonesia.go.id/narasi/indonesia-dalam-angka/ekonomi/kasuscovid-19-pertama-masyarakat-jangan-panik.

[17] Obuekwe, GI, \& Eze, R.-AI. (2017). Promoting Best Practice in Teaching and Learning in Nigerian Universities through Effective Elearning: Prospects and Challenges. International Conference Elearning, (pp. 184-188).

[18] Task Force for the Acceleration of Handling Covid-19. (2020, May 13). Infographics COVID-19 (13 May 2020). Retrieved from the Acceleration Task Force Handling Covid-19: https://covid19.go.id/p/berita/infogografi-covid-19-13-may-2020.

[19] Widyaningrum, GL. (2020, March 12). WHO Defines COVID-19 As Global Pandemic, What Does It Mean? Retrieved from National Geographic Indonesia. Retrieved April 03, 2021 from https://nationalgeographic.grid.id/read/ 132059249 / who-setcovid-19-as-pandemic-global-what do you mean.

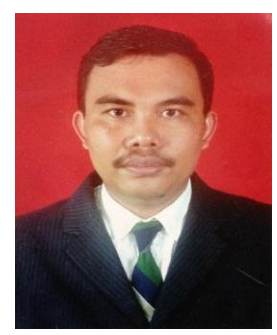

Gede Ginaya was born in Buleleng, Bali, Indonesia on $19^{\text {th }}$ September 1966. He is a permanent lecturer of English at Tourism Department, Politeknik Negeri Bali (PNB), Bali, Indonesia. He received a bachelor's degree in English language teaching from The Faculty of Education and Teacher Training Udayana University, Bali, Indonesia (Currently is UNDIKSHA Singaraja) in 1992 and a master's degree in cultural studies from the Faculty of Arts, Udayana University, Bali, Indonesia in 2010.

He has been assigned to teach English for Tourism in the three study programs of Tourism Department, Politeknik Negeri Bali, Indonesia. His research interests include classroom-action research, cultural studies, and tourism and have been published in several journals. His Email address: ginaya@pnb.ac.id

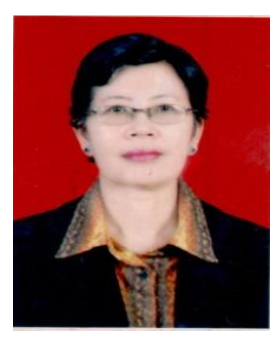

Ni Putu Somawati was born on $27^{\text {th }}$ of May 1966 in Denpasar, Bali, Indonesia. She is a permanent lecturer of English at Tourism Department, Politeknik Negeri Bali (PNB), Bali, Indonesia. She received a bachelor's degree in English Department, faculty of letters, Udayana University, Bali, Indonesia in 1987. She continued to master program in management and was awarded Magister Manajemen (MM) in Udayana University, Bali, Indonesia in 2005.

Her research interests include development tourism, English literature, English language teaching. Her Email address: putusomawati@pnb.ac.id

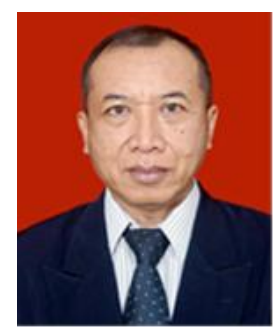

I Gusti Agung Bagus Mataram was born on $2^{\text {nd }}$ of July 1960 in Mataram, Nusa Tenggara Barat, Indonesia. $\mathrm{He}$ is a permanent lecturer of Information Technology subject and Computer Applications Basic subject at Tourism Department, Politeknik Negeri Bali (PNB), Bali, Indonesia. He received a bachelor's degree in Civil Engineering from Institut Teknologi Sepuluh Nopember (ITS) Surabaya in 1986 and Master of Information Technology from Edith Cowan University, Australia in 2005.

His research interests include computer network, digital marketing, tourism village, and tourism supply chain. His Email address: mataram@pnb.ac.id 